\title{
THE PSYCHEDELIC REINTERPRETATION OF CORPUS CHRISTI BY PHILIP K. DICK
}

\section{Bogdan Trocha}

Dr. hab., Professor,

University of Zielona Góra,

Poland, Zielona Góra

bwtrocha@gmail.com

\section{Троха Богдан}

доктор наук габілітований (філософія), професор, Університет Зелена Гура, Польща, м. Зелена Гура bwtrocha@gmail.com

\section{Троха Богдан}

доктор наук габилитованый (философия), профессор, Университет Зеленая Гура, Польша, г. Зеленая Гура bwtrocha@gmail.com
Abstract. The article discusses the literary search for God as given in the novel The Transmigration of Timothy Archer by Philip K. Dick. Religious, theological and fantastic contexts of the novel are analyzed here. The author also presents some cultural aspects of the novel. Set in the late 1960s and 1970s, it is one of the novels in his Valis triptych where the search for God and His hidden essence is fulfilled through traditional theological and philosophical texts of Judeo-Christian culture and gnosis. Its main protagonist, bishop Timothy Archer, is on a quest for uniting man with the infinite divine, coping with the juxtaposition of the official interpretation of religious texts and the newly discovered fragments of Zadokite texts. Studying these texts, Archer gains knowledge of the anokhi fungus, abandons the idea of contacting with God, and focuses on the practice of hallucinogenic communion that gives him the knowledge leading to the most suitable way to avoid the final experience of death. Tracing the shift in the main protagonist's worldview, the author shows us the dilemmas that a homo religiosus faces in his search of the divine caused by mistranslated texts. This article thus deals with the opposing phenomena of spiritual passivity and practical attitude towards the world, the religious ecstasy the protagonist seeks and the experience of narcotic trance he turns to in the end, and the manipulation of terms body of Christ' and the Fungus. Still, further research into the ecstatic experience and its role in culture is needed.

Keywords: sacrum, speculative fiction, gnostics, Judaism, Christianity, Philip K. Dick, interpretation of literary works.

Philip K. Dick's last three novels, forming the Valis (Dick, 2011) trilogy, are texts in which the author intensely and desperately seeks God, striving to discover His hidden essence. This search is carried out within the traditional theological and philosophical texts of Judeo-Christian culture and gnosis. Incidentally, 56-yearold Dick died after writing the last novel that made up the Valis triptych, namely Timothy Archer's Transmigration. Thus, the literary record of his quest took on an unintentional existential dimension, added by the writer's death, combining literary fiction with a human desire to escape to God, whose very presence explains the meaning of existence.

Transmigrations, like the whole Valis, were created in quite specific circumstances of the 1960s. When the texts from Qumran were published, it led to the appearance of the first speculations about the relationship between their content and the Bible, but also about the Gnostic thought contained in the apocryphal writings 
of the Qumran and Nag Hammadi collection. These speculations were loudly heard through their sensational theses, which were based on previous manipulations of the meaning of incomplete Gnostic codices (Teksty z Biblioteka z Nag-Hammadi, 1979), inserting lines in empty spaces, the content of which was the basis for reading these texts in a completely new, surprising context. Often quoted in Transmigrations, John Allegra, on whose idea of anokhi Dick's novel is based, was a controversial and noisy translator and interpreter of Qumran texts (The Biblical Collection) at the time. Until it turned out that his excellent theses published by him were the result of his own work of complementing the work of writers from Qumran, especially in those places where a change of context could lead to a change in the meaning of the entire text.

Those years were also marked by the great popularity in the US of Carlos Castaneda's books (Castaneda, 1968) and his pharmacological expeditions into the mystical reality of Yaqui Indian culture. This was compounded by the desire to experience mysticism and to explore the various practices that enable it, which was still quite common in circles fascinated by the rediscovered spirituality of the Far East. This has often led to purely intellectual speculation aimed at achieving the theoretical certainty on which a new model of human existence could be built. This is visible in the work of Allan Watts (Watts, 1947), whose figure also appears in Transmigrations, although hidden under a literary pseudonym. The desire for certainty concerning the description of an average mystical experience was not only to be an element of cognition, but the first time for us to have a scientific study, which was rather a moment on the way to meeting the divine presence, finding God, or forcing him to reveal the veil of mystery that hides him.

Although it may seem ridiculous today, in the 1960s there was in fact a leftist Bishop Jim Pike, who "indeed stood a trial for heresy and actually died in Palestine in the desert, seeking the living presence of God there" (Jęczmyk, 1999, p. 229). The figure of Pike is a model not only for the literary Bishop Archer, but also the porte-parole of Dick himself trying to rise above the texts describing God to his presence. Contact with the revealed texts was not enough for him, as he was not satisfied with faith alone. He wanted a living experience of God, an experience of salvation in the sense of liberation from the determinism of matter. His problem was only that he intended to realize his desire based on the gnosis derived from Paul's and kerygmatic theology and the apocryphal fiction of Allegra.

The search for Bishop Archer had begun even before he came into contact with the texts of the sadocites. It is significant that he focused his earlier attention on the texts of St. Paul concerning the body and presenting the key mystery of incarnation for Christianity. The dogma of the incarnation assumes that Jesus Christ as a Divine Person was fully human. This event of God's opening up and, in a way, de-Godness led not only to the divinization of the human body, but also brought about the theological concept of sola gratia presenting a model of salvation of a man through the grace of God dying on the cross. God whose body, i.e. the Corpus Christi, is for "the Church as a historically visible community that preserves unity (and in this bodily sense) (...) direct self-giving of God" (Rahner \& Vorgrimler, 1987, p. 64).

Paul's conceptualization of the body refers to soma, the body which, for theologians, appeared as a result of the existence in the world of the Messiah Christ in human redeeming form, which is essential for all creation. To him, "Soma means both the earthly and heavenly body, the unity of all men, here on earth subject to sin and death, but destined to be exalted and transformed by the pneuma" (Rahner \& Vorgrimler, 1987, p. 62).

Here Archer's search is still on the verge of heresy, but it is clear that he is heading for the gnosis. Within it, he wants to find a way to exalt the body without having to go through death, which is inscribed in Christian theology. Since this is possible according to Paul, and since the logs of Jesus Christ himself state that he is the resurrection, Archer will be looking for a mysterious element which is rather impossible to find within the religious reality.

His quest for an encounter, which he himself calls the experience of uniting man with the divine infinity, only partly coincides with mysticism in purely religious terms. Admittedly, in both cases, such a meeting has a sustaining power. Except that, as a rule, it is treated as an experience of a certain type of a gift. Only magic tries to subordinate the encounter to the divine power of its own will by special means. However, there is no place for magic in the biblical religious thinking.

Archer, who departs from the official interpreta- 
tion of religious texts, begins his search by juxtaposing the various combinations that the religious man's environment brings with it. As he does not consider revelation in the Word to be sufficient, assuming eo ipse the Mystery of God, which escapes any rational description, because even if it reveals itself, it does so as remaining hidden in the mystery that belongs to his essence. This forces the homo religiosus to use so-called heroic reason, i.e. one that trusts in the faith and accepts as certain judgments that are not rationalized. It is only on the basis of unconditionally accepted judgments that such reason begins to construct rational theses concerning the universe and a man. Archer does not accept such a cognitive model, but at the same time he wants to escape from the fear that comes not from the absence of God but from the awareness of the inevitability of death.

This behavior is classical for religion, but it has three different possibilities of realization. The main character rejects faith as not bringing solace to the fear of death, so there is no room for the Apollonian calm, characteristic of coming to terms with what is inevitable in the sophrosyne experience.

All that is left for him is to try to grasp the power on his own. This practice, known in antiquity under the term hybris, was considered the hardest speech against gods. It was usually associated with the use of narcotics, which were supposed to lead to a connection with God, forced by a man, who with the use of pharmaceuticals led to a mystical, completely extranational, yet real human experience of encounter with God. For the Greeks, the hybris was an act against deities destroying the harmony of the cosmos in the cosmos. This practice was treated as a manifestation of human pride, usually leading to the annihilation of a man. In the ancient culture, there are known descriptions of the bakhch practice, when "achieved by the bakhas (under the influence of wine) in ecstasy similarity to the gods is called hybrisma bakhon" (Van der Leeuw, 1997, p. 405).

Archer, as an erudite, was well aware that religious practices related to sacred vegetation were common in antiquity. They were supposed to give the divine life to the community as a sacrament. Such practices were found among the Persians (haoma) and Hindus? (soma) and were often quoted by the bishop to support his own search for the power to guarantee divine life.

Archer rejected the possibility of seeking salva- tion within the Church, which is the mystical Corpus Christi, thus rejecting the sacramental power of the Eucharist and Christian Christological dogmas. Salvation, which he understands quite specifically, can only be achieved through the knowledge of God. He thus avoids the duplication by his actions of the defeat of the bakh, who, while achieving a similarity with the gods, lost their autonomy becoming vessels of divine madness that most often brings tragedy to them or their surroundings. The bishop's idea is a safer way of achieving a liberating participation in divine power from death. Yet, the cognition in a mystical way did not suit him, and he accused the gnosis in the sense of the pure practices of speculative cognition, also with bitterness, as insufficient. The practices he analyzed did not allow him to go beyond the bounds of heroic reason, which accepted in an uncritical way the fact that it was up to the divine being to hide it from human cognition here and now. There would still be a third possibility to be taken up, the existence of which Archer was unaware until he met with the interpretations of the Zadokite texts by Allegra.

In these texts, the Hebrew term anokhi or anochi appears in the first sentences of the Book of Exodus (so there is no apocrypha). The sentence is: "I am the Lord your God, who brought you from the land of Egypt and from the house of bondage" [Ex. 20, 12] (Christian Art Publishers, 2017). The word anochi means "I" in the sentence "I am the Lord." The word itself obviously belongs to the Divine Being and is part of the epiphany. One of the few when God has made Himself known in it to the whole people chosen in an event in history. This gave the participants of these events the luxury of immersing themselves in the Divine presence, on the one hand, and, on the other hand, it gave hope for the repetition of this phenomenon.

However, it turns out that this term was used in "a special technical sense". It could not mean the Divine presence, because they say they had it in a literal sense, in the sixth document there is a poem: "Anochi dies and is reborn every year, and with each passing year there is more and more of it" (Dick, 1999, p. 68).

Further study of the Zadokite texts led Archer to discover that the term anochi meant a hallucinogenic fungus that was bred by the Sadducees in caves in the desert. This plant, which could not be fully identified, was, according to the Bishop, toxic. However, according to him, the Sadducees knew such techniques of preparing this fungus as a result of which it lost some of 
its toxic properties while retaining the hallucinogenic action so that after taking it they did not die but had visions. From this mushroom they prepared soup and bread, which they then consumed in a ritualistic manner. This is where Archer falls into total contradiction with the whole Semitic culture for which blood as a life-supporting element belonged to God and, hence, its sacramental power and symbolic presence in the sacrifice of body and blood. Replacing blood with plant juice while rejecting the dogma of transfiguration is an illogical confusion between the Bakkhis and the Messianic. However, it is easier to make contact with the fungus and its juice than with God hiding in the mysterious sacrament. Archer, who has gained knowledge of the fungus, completely rejects the idea of gaining contact with God as a result of participation in sacraments which, in their essence, did not seek to discover the mystery of the deity and focuses his attention only on the practice of hallucinogenic communion that gives knowledge without having to enter into a closer contact with the deity, too dangerous for a man. According to the Bishop, eating anokhi was to give the Zadokites immortality. In this way, Archer discovers the third way, the most optimal for him, because it excludes the necessity of the final experience of death. All that remains for him is to find a fungus and the whole reinterpretation of the kerygma concerning Corpus Christi.

Based on Allegra's translations of the falsified content of the texts and on his studies, he assumed behind him that "the early Christians were a secret sect of mushroom pickers" (Dick, 1999, p. 81). By the way of theological speculation, he also came to the more shocking conclusion that the plant was not only a fungus, or even a sacred plant. In order to be able to make a thesis about the divinity of the fungus, the fungus had to first overturn the dogma of Jesus' incarnation. To this end, he used the figure of the Explanator in the Zadokite scriptures, to which various Logs were attributed, i.e. sentences uttered by Jesus in the Gospels. Archer claimed that in such a state of affairs "the Explanator is the Son of God" (Dick, 1999, p. 72). Jesus becomes only a teacher representing a particular Jewish sect.

What is the mysterious anokhi fungus? If it gives immortality, it must have divine power. Archer does not make any moves to evoke the plant motifs of Gilgamesh for interpretation. Hence, his statement is that anokhi is the true Christ, the salvation-bearer of the Anointed One, sharing in the omnipotence of God. The divine power contained in the mushroom does not, strangely enough, arouse either fascination or horror, which are inherent in the experience of the sacrum, as if the sacrum could take on a different, hitherto unknown form, more human-friendly or, perhaps, even less different from all that is given to a man in his world. It awakens the desire to acquire some practical knowledge. Dick once again recalls Paul's texts from Tarsus, and he states that when he wrote about immortality he did not "speak metaphorically (1 Corinthians 15:12), people rise from the dead literally. They knew the techniques. It was science. They had anokhi in the Ueda" (Dick, 1999, p. 121).

The purpose of this knowledge about the practical use of anokhi was to avoid death. Yet, a brilliant and inquisitive theologian like Archer did not try to face a certain aporia that appeared here. Avoiding death on the way to the exaltation of the body to enjoy eternity means reversing the determinism given to the world by God creating it in the act of creation. Archer's reinterpretation rejects the salvation of all creation and accepts the selective salvation of chosen people in this place. Thus, we have to do either with the lack of divine omnipotence or with the possibility of being manipulated by man's plan of salvation inscribed in Semitic theologies, which is, thus, a proof of God's lack of omnipotence. God who is not almighty ceases to be God. Maybe this is why a new type of reading, as he put it, of the legend of Satan appears in Dick's least novels. Either way, depriving a deity of the omnipotence ascribed to his essence and treating him as a deity is only possible within the gnosis. In this way Dick combines what suits him in various theologies into a new hybrid whole. By losing the totality of the sacrum along the way, he gains the experience of a different dimension in the way of narcotic experiences and, in fact, of what allows him to reach the extranational dimensions, he will see a new type of divinity allowing him to rise above rationality, dreaming that this is the same as rising above the determinism of the world, which with the help of the hallucinogenic anokhi can leave at any time of his own free will. The search for hidden and salvific knowledge ceases to be merely a contemplative anticipation of the gift of mystical presence and gains the characteristics of experience characteristic of pharmacological mysticism. A man thus frees himself from the power of God hidden in the mystery and begins to decide his own fate rejecting God and the world 
so as to avoid death. Salvation is achieved by the one who comes to know God.

In this case, however, the path leading to the knowledge of God leads not through the sacrament of sharing in the sacrifice of the Body and Blood of Christ, but through consuming the hallucinogen which is the mysterious seat of power. A man himself begins to manipulate this power, which is characteristic of magical practices. Yet, there is nothing supernatural that is needed for magical actions, and we are dealing with the statement that "anokhi is pure awareness of God (...), God's wisdom" (Dick, 1999, p. 185) being in itself something supernatural. However, Archer does not mind this strange juxtaposition and does not destroy his inner conviction about the cohesion of his theory. Eating hallucinogen is supposed to fill him with wisdom. This mystical event is supposed to have a characteristic pharmacological mystique. The contact with a deity or power is forced by the man with a hallucinogenic agent that allows us to transcend the limitations of our rationality. In this case, however, the hallucinogen itself is seen as a deity. Therefore, incarnation does not concern the man but the fungus. Thus, the fungus stands above the man on a ladder in participation in holiness.

Divine wisdom is in its essence supernatural and thus irrational, and, yet, it can be given in the experience of narcotic ecstasy, which somehow excludes rationality showing other worlds. This, however, only remains a guess for the Bishop, since the final attempt to consume the prepared anokhi is out of the question until this mysterious fungus is found.

The Divine Wisdom consumed by the Sadducees fills, in his opinion, a new kerygma describing the possibility of escaping death here and now. What Gilgamesh and Enkidu failed to do is at hand. Gilgamesh's mystical topos returns. The desire to break away from determinism returns the world and the determinism of the phenomena. Human will is supported by the power of anokhi. This power acts in a way against the plan of salvation, which presupposes apocalyptic paralysis to take place when time is fulfilled. Now, however, Dick comes to the conclusion that God is not hiding in Transcendence, but rather in caves in the desert. This means that God is still present in our world, which is why Archer speaks of the Pariah that is happening now, that is, the Divine Presence, access to which allows one to break away from the determinism of death.
The Apocryphal Book of Penances, which is a part of the Zadokite collection, states that:

"I will die, but the flesh and blood of Christ will save me, (...) the Peninsula is, Archer said, a personification of fate (...) Christ, acting in the name of God here on earth (...) reads it (...) instructs man how to avoid his fate" (Dick, 2011, p. 194).

It turns out that the essence of Divine Wisdom is not to reverse the order of the Cosmos, because it cannot do so, which clearly contradicts the dogma of the omnipotence of God. Rather, Divine Wisdom is to help find a way to outsmart the Book. As you can see, Archer using the symbol of the Book is a part of the mystics such as Blake, Swedenborg and many others who, even when they fell into heresy, never questioned the truth about the existence of the Book and its Creator and the role of this hidden knowledge for human existence. They were mystical argonauts of the spirit, who were going down different paths to know what rational cognition escaped, and who showed that this cognition is also important to a man as well as rational cognition.

Archer, manipulating Paul of Tarsus' concept enabling him to build theories on how to avoid death, is not able to afford to accept the mysticism of St. John. The mysticism revealed in the experience of Patmos assumes the existence of the Gate of Death and is based on faith and grace. Archer's escape is an escape into the magical praxis.

Aware of the fact that the mystery is not embraced by human reason, he does not wait to see the truth through the eyes of the spirit in the apocalyptic reality, he escapes into the sphere of probabilism associated with pharmacological mysticism. Driving his "what if" at the source of his practice, he puts vetoes and expresses his disagreement with what he finds, characteristic of human magic. Escape into another world, given to a man in an ecstatic experience, is the result of escaping from the fear of death. The desire for the salvific certainty that comes from contact with the Divine Presence experienced not in the Word, but in concrete, lived experience, leads to narcotic visions. Yet, the vision itself is not the presence of God. Hence, the reality of Messiah's body is the reality of the anokhi fungus. God, the Messiah, is present in this world but remains hidden in the seduction.

This hiddenness has a double dimension. First, 
according to the Bishop, by Christian falsification of the anokhi mystery, God has been absent from religious communities for 2,000 years. This absence has led to the construction of a theological model of waiting for the fusion in a future unknown to anyone. Secondly, this fungus hides somewhere in caves in the desert, which are here on this earth. The search for God and the Divine Presence takes on a completely different, practical and real dimension. God's Wisdom hidden in anokhi found and consumed creates an opportunity to escape your own destiny.

The hope of obtaining Parusion, which he achieved through the reinterpretation of the mystery of Corpus Christi, becomes the engine of the search for anokhi in the desert. It is easier to search in the real dimension than in the reality of the words describing the apocalypse. The model of religious practice in which anokhi finds itself is characteristic of magical actions and, at the same time, of the contemporary desire for the theoretical subjugation of the world, which enables one to immerse oneself, through narcotic visions, in God's Wisdom.

There is no place where to wait for the gift of God.
Passivity is rejected in favor of a practical search, but this implies the conviction that it is only through the practice of narcotics that salvation is achieved, thus, rejecting the practice of spiritual enrichment inscribed in the participation of the mystical body of Christ. This fact does not change even the final call of the spirit of the deceased Archer, who took up existence in another body, which is characteristic of gnosis, to love, because it is more a matter of mercy on a particular person than of love for a man of species characteristic of the Bible.

The manipulation of the body of Christ - the "Fungus" so as to reach the mysteries of the Book and penetrate it leads to spiritual passivity, despite, paradoxically, the practical attitude towards the world. However, a man seeking salvation beyond sola fide and sola gratia cannot reject salvation beyond sola scripturae. The experience of narcotic trance, although easier to obtain than religious ecstasy, is, nevertheless, endowed with all the characteristics of contact, which seems to reopen the problem of research into the mystery of the ecstatic experience, of its role within the culture associated with the tradition of the mystical Book.

\section{References:}

Castaneda, Carlos. (1968). The Teachings of Don Juan: A Yaqui Way of Knowledge. University of California Press.

Christian Art Publishers. (2017). The Holy Bible. DOI: https://doi.org/10.3406/jatba.1974.3160

Dick, Philip K. (1999). Transmigracje Timothy'ego Archera [The Transmigration of Timothy Archer]. Wydanie oryginalne: 1982 (trans. by L. Jęczmyk). Poznań: Dom Wydawniczy Rebis.

Dick, Philip K. (2011). Valis. (trans. by L. Jęczmyk). Poznań: Dom Wydawniczy Rebis.

Jęczmyk, Lech. (1999). Od thumacza, [in:] Ph. K. Dick, Transmigracje Timothy'ego Archera, trans. by L. Jęczmyk. Poznań: Dom Wydawniczy Rebis.

Rahner, Karl \& Vorgrimler, Herbert. (1987). Maty stownik teologiczny [A small theological dictionary]. Trans. by T. Mieszkowski, \& P. Pachciarek. Warszawa: Wydawnictwo PAX.

Teksty z Biblioteka z Nag-Hammadi. (1979). Trans. by. Albertyna Dembska i Wincenty Myszor, elaboration, introduction and commentary Wincenty Myszor. Warszawa: Akademia Teologii Katolickiej.

The Biblical Collection at the Qumran Library . (No date). Retrieved from veracityomadden.com. [dostęp 2013-07-15]. Van der Leeuw, Gerardus. (1997). Fenomenologia religii [Religion in Essence and Manifestation: A Study in Phenomenology]. Trans. by J. Prokopiuk. Warszwa: Wydawnictwo Książka i Wiedza.

Watts, Alan. (1947). Behold the Spirit: A Study in the Necessity of Mystical Religion. New York: Pantheon Books. 


\section{Троха Богдан}

\section{Психоделічна реінтерпретація Тіла Господнього за Філіпом К. Діком}

Анотація. У статті досліджуються літературні пошуки Бога за романом «Трансміграція Тимоті Арчера» Філіпа К. Діка. Проаналізовані релігійний, богословський та фантастичний контексти роману. Автор також демонструє деякі культурні аспекти роману. Дія твору відбувається наприкінці 1960-х та 1970-х років. У розвідці аналізується одна із частин триптиху «ВАЛІС», де пошук Бога та Його прихованої сутності здійснюється за допомогою традиційних богословських та філософських текстів іудео-християнської культури та гнозису. Ї̈і головний герой єпископ Тимоті Арчер шукає єднання людини з нескінченним Божеством, борючись зі протиріччям офіційної інтерпретації релігійних текстів та нововиявлених фрагментів текстів садукеїв (Дамаського документа). Вивчаючи ці тексти, Арчер отримує знання про грибок анокі, відмовляється від ідеї контакту з Богом і зосереджується на практиці галюциногенного спілкування, що дає йому знання, які ведуть до найбільш дієвого способу уникнути остаточного досвіду смерті. Прослідковуючи зміну світогляду головного героя, автор показує нам дилеми, з якими стикається людина релігійна в пошуках божественного, спричинених хибно перекладеними текстами. Ця стаття, таким чином, стосується протилежних явищ духовної пасивності та практичного ставлення до світу, релігійного екстазу, до якого головний герой прагне, досвіду наркотичного трансу, до якого він звертається зрештою, та маніпулювання термінами «тіло Христа» та Гриба. Автор зауважує щодо необхідності подальших досліджень екстатичного досвіду та його ролі в культурі.

Ключові слова: сакрам, спекулятивна фантастика, гностики, іудаїзм, християнство, Філіп К. Дік, інтерпретація літературних творів.

\section{Троха Богдан \\ Психоделическая реинтерпретация Тела Господнего по Филиппу К. Дику}

Аннотащия. В статье исследуются литературные поиски Бога по роману «Трансмиграция Тимоти Арчера» Филиппа К. Дика. Проанализированы религиозный, богословский и фантастический контексты романа. Автор также демонстрирует некоторые культурные аспекты романа. Действие произведения происходит в конце 1960-х и 1970-х годов. В исследовании анализируется одна из частей триптиха «ВАЛЛИС», где поиск Бога и Его скрытой сущности осуществляется с помощью традиционных богословских и философских текстов иудео-христианской культуры и гнозиса. Ее главный герой епископ Тимоти Арчер ищет единения человека с бесконечным Божеством, борясь с противоречием официальной интерпретации религиозных текстов и вновь открывшихся фрагментов текстов садукеев (Дамасского документа). Изучая эти тексты, Арчер получает знания о грибке аноки, отказывается от идеи контакта с Богом и сосредотачивается на практике галлюциногенного общения, что дает ему знания, которые ведут к наиболее действенному способу избежать окончательного опыта смерти. Отслеживая изменение мировоззрения главного героя, автор показывает нам дилеммы, с которыми сталкивается человек религиозный в поисках божественного, вызванные неправильно переведенными текстами. Эта статья, таким образом, касается противоположных явлений духовной пассивности и практического отношения к миру, религиозного экстаза, к которому главный герой стремится, опыта наркотического транса, к которому он обращается в конце концов, и манипулирования терминами «тело Христа» и Гриба. Автор говорит о необходимости дальнейших исследований экстатического опыта и его роли в культуре.

Ключевые слова: сакрам, спекулятивная фантастика, гностики, иудаизм, христианство, Филипп К. Дик, интерпретация литературных произведений. 